\title{
Replanting Model of Palm Oil with Paludiculture System on Peatland in South Kalimantan (Soil Physical Characteristics and Optimize Analysis)
}

\author{
Taufik Hidayat, Fakhrur Razie, Yudi Ferrianta, Rifiana
}

\begin{abstract}
Efforts to accelerate the development of smallholder plantations in the plantation revitalization program are carried out through expansion, rejuvenation and rehabilitation of estate crops. however, the problem faced by farmers today is the fear of farmers losing their livelihoods if their oil palms are rejuvenated. On the other hand, peat ecosystem is an ecosystem that is very important role in maintaining environmental sustainability, especially related to the issue of global warming. one way that can be taken to prevent widespread damage on peatlands and to prevent future loss of community livelihoods by applying paludiculture planted on peatlands. the paludikulture model is a multiple cropping system in peatlands that can be adopted in oil palm areas. The results showed that the status of soil fertility in the area of oil palm rejuvenation has a relatively better soil fertility status when compared to mineral material, which has a range of status from low to moderate. Whereas mineral soil material has a low soil fertility status. This is concluded, although the cation exchange capacity of this soil sample is classified as high, but the cause of the low soil is the $P$-total, $K$-total and $C$-organic content is classified as very low to low. The results of the analysis of farmer optimization show that the optimal cropping pattern of vegetable farmers is commodity long beans + cucumbers. With farm income at optimal conditions is $R p$ 4,289,944 per year or $R p 18,619,548$ per hectare per year.
\end{abstract}

Keywords: Palm oil replanting model, paludiculture, Optimize analysis.

\section{INTRODUCTION}

Efforts to accelerate the development of smallholder plantations in the plantation revitalization program are carried out through expansion, rejuvenation, and rehabilitation of estate crops. The plantation revitalization program is supported by investment loans and interest subsidies provided by the government through collaboration with companies in the plantation business as development

Revised Manuscript Received on January 5, 2020.

* Correspondence Author

Taufik Hidayat*, Department of Agribusiness, Faculty of Agriculture, Lambung Mangkurat University, Banjarbaru City, Indonesia.

Email: Taufikkdg@yahoo.com

Fakhrur Razie, Department of Soil Science, Faculty of Agriculture, Lambung Mangkurat University, Banjarbaru City, Indonesia. Email: fakhrur.razie@ulm.ac.id

Yudi Ferrianta, Department of Agribusiness, Faculty of Agriculture, Lambung Mangkurat University, Banjarbaru City, Indonesia.

Email: ferrianta@gmail.com

Rifiana, Department of Agribusiness, Faculty of Agriculture, Lambung Mangkurat University, Banjarbaru City, Indonesia.

Email: rifiana.ulm@gmail.com partners in the development, processing, and marketing of the results of these plantations.

Steps that can be taken to prevent widespread damage on peatlands and to prevent future loss of community livelihoods by applying paludiculture planted on peatlands. Paludiculture is defined as a cultivation of plants using swamp or wetland plants that do not require peat water drainage, but in practice, these activities must be carried out on time (before the peatlands experience permanent/severe inundation) and the types of species to be planted adjusted to the dynamics of inundation that occur and is expected to have high economic value.

One key factor that needs attention in the context of the application of paludiculture in Indonesia is the active involvement of the community with support and capacity development, learning and success that the community has experienced about paludiculture need to be promoted, replicated and mainstreamed as the best and fair peatland management model. The management of paludiculture practices needs to be an example of oil palm plantations in their peatland management practices.

The paludiculture model is multiple cropping systems in peatlands that can be adopted in oil palm areas. Until now the paludiculture model is mainly in forestry plants such as sago, galam, jelutung, and wood-producing plants such as ramin. So that in this study a palm oil-based paludiculture model was built that would later provide recommendations to increase income and maintain the continuity of income of oil palm farmers, especially when rejuvenating oil palm plants

In terminology, paludiculture is a new term and is not widely known by the people in Indonesia. The word paludiculture comes from the Latin (palus) meaning swamp. Swamp forest ecosystems (including peat swamps) are forests that grow in areas that are always inundated, not affected by climate, but can be affected by tides. Paludiculture means productive use of swamps (and peat swamps) in ways that protect peat. Water-saturated peat and swamp conditions are maintained without drainage, even in drained conditions, efforts will be made to close drainage or waterways so that the peat will get wet again (Joosten et al., 2012). Furthermore, Biancalani \& Avyagan (2014) explained that paludiculture is alternative management of responsible peatlands. The paludiculture system can maintain peat conditions and produce biomass in wet and re-wet peatland conditions, maintain ecosystem services and can provide carbon accumulation. Paludiculture products can provide food, feed, fiber, and fuel, as well as wood industry raw materials.

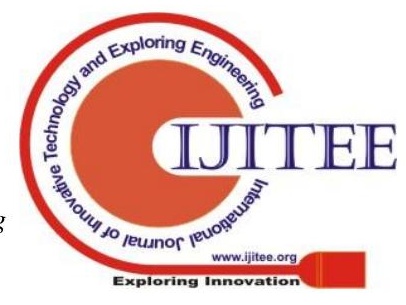




\section{Replanting Model of Palm Oil with Paludiculture System on Peatland in South Kalimantan (Soil Physical Characteristics and Optimize Analysis)}

The research aims to study the biophysical and chemical model of rejuvenation palm paludiculture system and assessment of socio-economic and models optimize the rejuvenation of palm with paludiculture system.

\section{MATERIALS AND METHODS}

\section{A. Method of Analysis of biophysical studies}

The paludiculture model experiment will be carried out on an area of 4 ha, each with an area of $2 \times 1$ ha of a palm rejuvenation model with a paludiculture system and an area of $2 \times 1$ ha of an oil palm rejuvenation model with an intercropping system on peat or peatlands. After conducting a biophysical study, the land will proceed with land preparation by dividing the 4 ha area into 41 ha plots based on the model to be applied

The treatment will be given on a model rejuvenation of palm oil, which is used paludiculture system and the use of intercropping systems. Paludiculture system is an intercropping system by providing OPEFB biomass/oil palm biomass before it has been composted and the groundwater level adjustment does not exceed $40 \mathrm{~cm}$ (SP). The intercropping system is intensive inter-crop management through inorganic fertilizer and palm oil biomass compost and groundwater level not exceeding $60 \mathrm{~cm}$. The two treatments will be repeated 2 times or two trial plots with a size of 1 ha.

Water management is done by making canals and blocking (canal blocking) to maintain water availability. Water management on field trials to keep it wet is done by managing micro water systems. This water system is carried out by utilizing a micro water channel which has a dual role, namely as a drainage channel when there is excessive water and as an irrigation channel during the dry season/lack of water, where this channel will be made of water gates using pipes while functioning to regulate water levels according to treatment. Sketch of the layout of plants and water systems on 1 ha of experimental land for the paludiculture system or intercropping are presented in the Figure below.

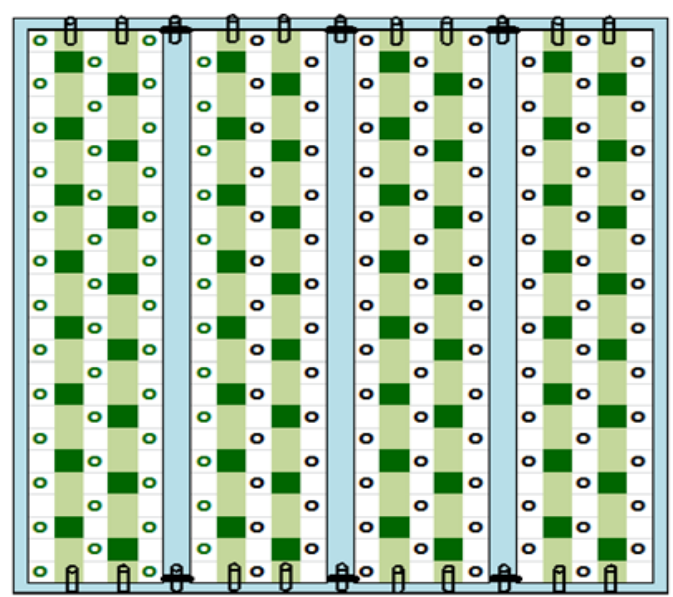

Fig 1. Planting patterns and procedures to manage water in the peat

\section{B. Analysis of Plant Pattern Optimization}

The main objective desired by farmers from farming activities is to obtain the maximum profit to improve family welfare and to develop their business activities. Efforts that can be done by farmers in maximizing their income are by choosing a combination of crop types and optimal allocation of resources. The optimal combination of plant types and resources can be obtained by analyzing the optimization using Linear Programming.

Production activities are activities producing certain types of annual crops for sale. These activities are distinguished by the planting season, ie planting seasons 1, 2, and 3 . Mathematically, the linear programming model is shown in the following equation:

Maks $Z=-\sum_{i=1}^{3} \sum_{j=1}^{n} c_{i j} L_{i j}-\sum_{i=1}^{3} \sum_{k=1}^{n} U_{i k} P_{i k}-\sum_{i=1}^{3} \sum_{a=1}^{2} o_{i \alpha} T_{i a}+\sum_{i=1}^{3} \sum_{j=1}^{n} H_{i j} Q_{i j}$

Where,

\begin{tabular}{|l|l|l|}
\hline $\mathrm{I}$ & $:$ & planting season, $\mathrm{i}=1,2,3$ \\
\hline $\mathrm{J}$ & $:$ & type of commodity, $\mathrm{j}=1,2,3, \ldots, \mathrm{n}$ \\
\hline $\mathrm{K}$ & $:$ & type of fertilizer, $\mathrm{k}=1,2,3, \ldots, \mathrm{n}$ \\
\hline $\mathrm{A}$ & $:$ & type of labor, $\mathrm{a}=1.2$ \\
\hline $\mathrm{Z}$ & $:$ & maximize revenue \\
\hline $\mathrm{C}_{\mathrm{ij}}$ & $:$ & other costs incurred $(\mathrm{Rp} / \mathrm{ha})$ for commodity $\mathrm{j}$ in PS $\mathrm{i}$ \\
\hline $\mathrm{L}_{\mathrm{ij}}$ & $:$ & land area (hectare) used for commodity $\mathrm{j}$ in PS $\mathrm{i}$ \\
\hline $\mathrm{U}_{\mathrm{ik}}$ & $:$ & purchase price of fertilizer $(\mathrm{Rp} / \mathrm{kg}$ ) type $\mathrm{k}$ in PS to $\mathrm{i}$ \\
\hline $\mathrm{P}_{\mathrm{ik}}$ & $:$ & amount of fertilizer $(\mathrm{kg})$ type $\mathrm{k}$ purchased in PS to $\mathrm{i}$ \\
\hline $\mathrm{O}_{\mathrm{ia}}$ & $:$ & wage rate $(\mathrm{Rp} / \mathrm{HOK})$ type workers in PS to $\mathrm{i}$ \\
\hline $\mathrm{T}_{\mathrm{ia}}$ & $:$ & the number of workers (HOK) type a hired on PS to $\mathrm{i}$ \\
\hline $\mathrm{H}_{\mathrm{ij}}$ & $:$ & level of the selling price (Rp) of commodities produced in PS to $\mathrm{i}$ \\
\hline $\mathrm{Q}_{\mathrm{ij}}$ & $:$ & the number of commodities $\mathrm{j}(\mathrm{kg})$ produced in PS to $\mathrm{i}$ \\
\hline & & PS = planting season \\
\hline
\end{tabular}

\section{RESULTS AND DISCUSSION}

\section{A. Interpretation of chemical properties and soil fertility status}

\section{- Soil Texture}

The soil texture in the two measured observation blocks is presented in Table 1. Soil samples in the oil palm rejuvenation area measured had the same texture class, namely dusty clay texture with sand, dust and clay composition respectively $1.21-12.84 \%$ sand; 41.92 $51.31 \%$ dust and 42.10 - $50.90 \%$ clay. This condition illustrates that the area is not porous, so when the tide of land the area of oil palm rejuvenation is often flooded. This also causes a layer of peat even with a depth of less than $50 \mathrm{~cm}$ or the formation of a peat layer.

Table-I. Physical properties (texture) of the soil

\begin{tabular}{|c|c|c|c|c|l|}
\hline $\begin{array}{c}\text { sample } \\
\text { number }\end{array}$ & sand $(\%)$ & dust $(\%)$ & clay $(\%)$ & Total $\%$ & texture class \\
\hline TS1 & 1.21 & 47.89 & 50.90 & 100.00 & dusty clay \\
\hline TS2 & 12.84 & 41.92 & 45.24 & 100.00 & dusty clay \\
\hline TS3 & 6.59 & 51.31 & 42.10 & 100.00 & dusty clay \\
\hline TS4 & 8.32 & 48.86 & 42.82 & 100.00 & dusty clay \\
\hline
\end{tabular}

- Soil Organic Ingredients

The results of measurements of C-organic, N-total and C / N Soil content can be seen in Table II. The organic C content of peat soil material measured is still very high, even though the content is already far below the $\mathrm{C}$-organic content of peat material in general. The existence of agricultural and plantation activities on the land causes a decrease in the content. While the C-organic content of mineral soil materials varies from very low (0.12\% C-organic) to moderate $(2.53 \% \mathrm{C}$-organic). 
Table-II. The $\mathrm{C}$ organic, $\mathrm{N}$ total and $\mathrm{C} / \mathrm{N}$ soil content

\begin{tabular}{|c|c|c|c|c|c|c|c|c|}
\hline \multirow{2}{*}{$\begin{array}{l}\text { sample } \\
\text { number }\end{array}$} & \multirow{2}{*}{$\begin{array}{c}\text { Soil } \\
\text { material }\end{array}$} & \multirow{2}{*}{ depth } & \multicolumn{2}{|c|}{$\mathrm{C}$ organic } & \multicolumn{2}{|c|}{$\mathrm{N}$ total } & \multicolumn{2}{|c|}{$\mathrm{C} / \mathrm{N}$} \\
\hline & & & $\%$ & status & $\%$ & Status & - & $\begin{array}{c}\text { Stat } \\
\text { us }\end{array}$ \\
\hline TS1 & \multirow{4}{*}{ peat soil } & \multirow{4}{*}{$\begin{array}{l}<30 \\
\mathrm{~cm}\end{array}$} & 5.38 & ST & 0.56 & $\mathrm{~T}$ & 9.61 & $\mathrm{R}$ \\
\hline TS2 & & & 8.42 & ST & 0.54 & $\mathrm{~T}$ & 15.59 & $\mathrm{~T}$ \\
\hline TS3 & & & 5.81 & ST & 0.42 & S & 13.83 & $S$ \\
\hline TS4 & & & 5.86 & ST & 0.25 & $S$ & 23.44 & $\mathrm{~T}$ \\
\hline TS1 & \multirow{4}{*}{ Mineral } & \multirow{4}{*}{$>1 \mathrm{~m}$} & 2.53 & S & 0.11 & $\mathrm{R}$ & 23.00 & $\mathrm{~T}$ \\
\hline TS2 & & & 2.13 & $S$ & 0.13 & $\mathrm{R}$ & 16.38 & $\mathrm{~T}$ \\
\hline TS3 & & & 0.12 & SR & 0.12 & $\mathrm{R}$ & 1.00 & SR \\
\hline TS4 & & & 0.16 & SR & 0.16 & $\mathrm{R}$ & 1.00 & SR \\
\hline
\end{tabular}

Where: $S R=$ very low, $R=$ low, $S=$ medium, $T=$ high, $S T=$ very high, $S M=$ very acidity

\section{- P-total and P-available Land}

The P-total and P-available content of soils in oil palm rejuvenation lands are presented in Table III. The two soil materials in the region have different total $\mathrm{P}$ content if the peat soil has moderate to very high status $(2.78-179.66 \mathrm{mg}$ $\left.\mathrm{P}_{2} \mathrm{O}_{5} / 100 \mathrm{~g}\right)$ while mineral soils have low status $(11,77$ $17.32 \mathrm{mg} \mathrm{P}_{2} \mathrm{O}_{5} / 100 \mathrm{~g}$ ). However, when viewed from the $\mathrm{P}$-content available in both soil materials, the status is very low except at one of the observation points with $\mathrm{R}$ status in mineral-based soils. The status of available peat material is in the range of $2.35-3.17$ ppm $\mathrm{P}_{2} \mathrm{O}_{5}$ and mineral materials 4.01 - 10.76 ppm $\mathrm{P}_{2} \mathrm{O}_{5}$.

Table-III. The P-total and P-available content

\begin{tabular}{|c|c|c|c|c|c|c|}
\hline \multirow[b]{2}{*}{$\begin{array}{l}\text { sample } \\
\text { number }\end{array}$} & \multirow[b]{2}{*}{$\begin{array}{c}\text { Soil } \\
\text { material }\end{array}$} & \multirow[b]{2}{*}{ depth } & \multicolumn{2}{|c|}{ P-total } & \multicolumn{2}{|c|}{ P-available } \\
\hline & & & $\begin{array}{c}\mathrm{mg} \\
\mathrm{P}_{2} \mathrm{O}_{5} / 100 \mathrm{~g}\end{array}$ & Status & $\begin{array}{l}\mathrm{ppm} \\
\mathrm{P}_{2} \mathrm{O}_{5}\end{array}$ & $\begin{array}{l}\mathrm{St} \\
\text { at } \\
\text { us }\end{array}$ \\
\hline TS1 & \multirow{4}{*}{ Peat soil } & \multirow{4}{*}{$<30 \mathrm{~cm}$} & 26.78 & S & 2.57 & $\begin{array}{l}S \\
R\end{array}$ \\
\hline TS2 & & & 70.68 & ST & 3.17 & $\begin{array}{l}S \\
R\end{array}$ \\
\hline TS3 & & & 63.31 & ST & 2.67 & $\begin{array}{l}S \\
R\end{array}$ \\
\hline TS4 & & & 179.66 & ST & 2.35 & $\begin{array}{l}S \\
R\end{array}$ \\
\hline TS1 & \multirow{4}{*}{ Mineral } & \multirow{4}{*}{$>1 \mathrm{~m}$} & 14.77 & $\mathrm{R}$ & 4.01 & $\begin{array}{l}S \\
R\end{array}$ \\
\hline TS2 & & & 17.32 & $\mathrm{R}$ & 8.99 & $\begin{array}{l}S \\
R\end{array}$ \\
\hline TS3 & & & 12.50 & $\mathrm{R}$ & 6.21 & $\begin{array}{l}\mathrm{S} \\
\mathrm{R}\end{array}$ \\
\hline TS4 & & & 11.77 & $\mathrm{R}$ & 10.76 & $\mathrm{R}$ \\
\hline
\end{tabular}

Where: $S R=$ very low $R=$ low, $S=$ medium, $T=$ high, $S T=$ very high, SM=very acidity

\section{- K-total and K-available Land}

In Table IV, it can be seen that the total K-content of peat material ranges from $26.78 \mathrm{mg} \mathrm{K} 2 \mathrm{O} / 100 \mathrm{~g}$ to $29.42 \mathrm{mg}$ $\mathrm{K}_{2} \mathrm{O} / 100 \mathrm{~g}$ is of moderate status, while the total $\mathrm{K}$ content of minerals ranges from $11.77 \mathrm{mg} \mathrm{K}_{2} \mathrm{O} / 100 \mathrm{~g}$ to $46.57 \mathrm{mg} \mathrm{K}_{2} \mathrm{O}$ $/ 100 \mathrm{~g}$ are low to high status. The $\mathrm{K}$ content available in peat materials ranges from 0.11 and 0.16 me $\mathrm{K} / 100 \mathrm{~g}$ including low to moderate status. In mineral soil material the $\mathrm{K}$ content available is very low to low (0.05 -0.16 me K/ $100 \mathrm{~g})$.
Table-IV. K-total and K-available content

\begin{tabular}{|c|c|c|c|c|c|c|}
\hline \multirow{2}{*}{$\begin{array}{l}\text { sample } \\
\text { number }\end{array}$} & \multirow{2}{*}{$\begin{array}{c}\text { Soil } \\
\text { materi } \\
\text { al }\end{array}$} & \multirow[b]{2}{*}{ depth } & \multicolumn{2}{|c|}{ K-total } & \multicolumn{2}{|c|}{ K- available } \\
\hline & & & $\begin{array}{c}\mathrm{mg} \\
\mathrm{K}_{2} \mathrm{O} / 100 \mathrm{~g}\end{array}$ & Status & $\begin{array}{c}\text { me } \\
\mathrm{K} / 100 \mathrm{~g}\end{array}$ & Status \\
\hline TS1 & \multirow{4}{*}{$\begin{array}{l}\text { Peat } \\
\text { soil }\end{array}$} & \multirow{4}{*}{$\begin{array}{l}<30 \\
\mathrm{~cm}\end{array}$} & 26.78 & $\mathrm{~S}$ & 0,11 & $\mathrm{R}$ \\
\hline TS2 & & & 29.42 & $\mathrm{~S}$ & 0,31 & $\mathrm{~S}$ \\
\hline TS3 & & & 27.68 & S & 0,16 & $\mathrm{R}$ \\
\hline TS4 & & & 28.29 & $\mathrm{~S}$ & 0,16 & $\mathrm{R}$ \\
\hline TS1 & \multirow{4}{*}{$\begin{array}{c}\text { Miner } \\
\text { al }\end{array}$} & \multirow{4}{*}{$>1 \mathrm{~m}$} & 46.57 & $\mathrm{~T}$ & 0,09 & SR \\
\hline TS2 & & & 17.32 & $\mathrm{R}$ & 0,05 & SR \\
\hline TS3 & & & 12.50 & $\mathrm{R}$ & 0,11 & $\mathrm{R}$ \\
\hline TS4 & & & 11.77 & $\mathrm{R}$ & 0,07 & SR \\
\hline
\end{tabular}

Where: $S R=$ very low, $R=$ low $S=$ medium, $T=$ high, $S T=$ very high, $S M=$ very acidity

\section{- Calcium, Magnesium, and Sodium can be exchanged}

The content of cations can be exchanged in the soil can be seen in Table $\mathrm{V}$. The content of $\mathrm{Ca}$ and $\mathrm{Mg}$ can be exchanged on both soil materials, each of which has a very low status for interchangeable $\mathrm{Ca}(0.16$ - $1.02 \mathrm{me} \mathrm{Ca} / 100 \mathrm{~g})$ and low status for $\mathrm{Mg}$ can be exchanged. While the $\mathrm{Na}$ content can be exchanged on peat materials ranging from $0.17 \mathrm{me} \mathrm{Na} / 100 \mathrm{~g}$ (low) to 0.39 me Na / 100g (low). Na content can be exchanged on low-status mineral soils with a range of 0.22 $0.30 \mathrm{me} \mathrm{Na} / 100 \mathrm{~g}$.

Table-V. Content of Ca, Mg and Na can be exchanged

\begin{tabular}{|c|c|c|c|c|c|c|c|c|}
\hline \multirow{2}{*}{$\begin{array}{l}\text { sample } \\
\text { number }\end{array}$} & \multirow{2}{*}{$\begin{array}{c}\text { Soil } \\
\text { material }\end{array}$} & \multirow{2}{*}{ depth } & \multicolumn{2}{|c|}{$\begin{array}{l}\text { Ca-can be } \\
\text { change }\end{array}$} & \multicolumn{2}{|c|}{$\begin{array}{l}\mathrm{Mg}-\text { can be } \\
\text { change }\end{array}$} & \multicolumn{2}{|c|}{$\begin{array}{l}\text { Na- can be } \\
\text { change }\end{array}$} \\
\hline & & & \begin{tabular}{|c|} 
me \\
$\mathrm{Ca} / 100 \mathrm{~g}$
\end{tabular} & Status & $\begin{array}{c}\mathrm{me} \\
\mathrm{Mg} / 100 \mathrm{~g}\end{array}$ & Status & $\begin{array}{c}\text { me } \\
\mathrm{Na} / 100 \mathrm{~g}\end{array}$ & Status \\
\hline TS1 & \multirow{4}{*}{ Peat soil } & \multirow{4}{*}{$<30 \mathrm{~cm}$} & 0.16 & SR & 0.16 & $\mathrm{R}$ & 0.35 & $\mathrm{R}$ \\
\hline TS2 & & & 0.18 & SR & 0.18 & $\mathrm{R}$ & 0.39 & $\mathrm{~S}$ \\
\hline TS3 & & & 0.45 & SR & 0.30 & $\mathrm{R}$ & 0.22 & $\mathrm{R}$ \\
\hline TS4 & & & 0.17 & SR & 0.17 & $\mathrm{R}$ & 0.17 & $\mathrm{R}$ \\
\hline TS1 & \multirow{4}{*}{ Mineral } & \multirow{4}{*}{$>1 \mathrm{~m}$} & 0.60 & SR & 0.15 & $\mathrm{R}$ & 0.26 & $\mathrm{R}$ \\
\hline TS2 & & & 0.45 & SR & 0.15 & $\mathrm{R}$ & 0.22 & $\mathrm{R}$ \\
\hline TS3 & & & 1.02 & SR & 0.15 & $\mathrm{R}$ & 0.30 & $\mathrm{R}$ \\
\hline TS4 & & & 0.69 & SR & 0.27 & $\mathrm{R}$ & 0.22 & $\mathrm{R}$ \\
\hline
\end{tabular}

Where: $S R=$ very low, $R=$ low, $S=$ medium, $T=$ high, $S T=$ very high, $S M=$ very acidity

\section{- Cation Exchange Capacity, Base Saturation, and Aluminum and Soil Acidity}

The results of measurements of cation exchange capacity, base saturation, $\mathrm{Al}$ saturation, and soil acidity are presented in Table 6. The second CEC for soil material in the oil palm rejuvenation area shows the same status, which is classified as high. CEC Peat materials ranged from $29.06 \mathrm{me} / 100 \mathrm{~g}$ to $37.18 \mathrm{me} / 100 \mathrm{~g}$ material and CEC mineral materials ranged from $23.25 \mathrm{me} / 100 \mathrm{~g}$ to $27.26 \mathrm{me} / 100 \mathrm{~g}$. On the contrary, the two KBs of soil material in the region are classified as very low. Base saturation in peat material ranges from $1.84 \%$ to $3.57 \%$ while in mineral materials $3.34 \%$ to $6.30 \%$. This condition is suspected to have a washing process or there is a tidal movement of water in the region which causes the washing of exchanged bases. Al saturation in mineral-based soils in this region is high to very high. This is in line with the low $\mathrm{pH}$ value of this mineral soil material which reaches $3.65-4.25$ (very sour status). Even though the $\mathrm{pH}$ of the peat material is relatively higher when compared, in general, it is still classified as very acid and sour. So that in the management of this land the ameliorant action is needed, both in the form of compost and liming. 
Table-VI. KTK, KB, Al saturation and soil acidity

\begin{tabular}{|c|c|c|c|c|c|c|c|c|c|c|}
\hline \multirow{2}{*}{$\begin{array}{l}\text { sample } \\
\text { number }\end{array}$} & \multirow{2}{*}{ Soil material } & \multirow{2}{*}{ depth } & \multicolumn{2}{|c|}{ KTK } & \multicolumn{2}{|c|}{$\mathrm{KB}$} & \multicolumn{2}{|c|}{$\mathrm{Al}$ saturation } & \multicolumn{2}{|c|}{$\mathrm{pH}(\mathrm{H} 2 \mathrm{O})$} \\
\hline & & & $\mathrm{me} / 100 \mathrm{~g}$ & Status & $\%$ & Status & $\%$ & Status & - & Status \\
\hline TS1 & \multirow{4}{*}{$\begin{array}{c}\text { Peat } \\
\text { soil }\end{array}$} & \multirow{4}{*}{$<30 \mathrm{~cm}$} & 33.41 & $\mathrm{~T}$ & 2.34 & SR & - & & 4.01 & SM \\
\hline TS2 & & & 35.53 & $\mathrm{~T}$ & 2.89 & SR & - & & 4.10 & SM \\
\hline TS3 & & & 29.06 & $\mathrm{~T}$ & 3.57 & SR & - & & 4.14 & SM \\
\hline TS4 & & & 37.18 & $\mathrm{~T}$ & 1.83 & SR & - & & 4.69 & $\mathrm{M}$ \\
\hline TS1 & \multirow{4}{*}{ Mineral } & \multirow{4}{*}{$>1 \mathrm{~m}$} & 27.26 & $\mathrm{~T}$ & 4.01 & SR & 30.96 & $\mathrm{~T}$ & 3.65 & SM \\
\hline TS2 & & & 25.85 & $\mathrm{~T}$ & 3.34 & SR & 37.21 & $\mathrm{~T}$ & 3.99 & SM \\
\hline TS3 & & & 25.15 & $\mathrm{~T}$ & 6.30 & SR & 137.46 & ST & 3.79 & SM \\
\hline TS4 & & & 23.25 & $\mathrm{~T}$ & 5.36 & SR & 138.06 & ST & 4.25 & SM \\
\hline
\end{tabular}

Where: $\mathrm{SR}=$ very low, $\mathrm{R}=$ low, $\mathrm{S}=$ medium, $\mathrm{T}=$ high, $\mathrm{ST}=$ very high, $\mathrm{SM}=$ very acidity

\section{- Soil Fertility Status}

The status of soil fertility in the area of rejuvenation of Palm Oil in both materials can be seen in Table VII. Soil peat material has relatively better soil fertility status compared to mineral material, which has a range of status from low to moderate. Whereas mineral soil material has a low soil fertility status. This is concluded, although the CEC of this soil sample is classified as high, the cause of the low soil is the total P-total, K-total, and C-organic content is classified as very low to low.

\section{Table-VII. Soil fertility status}

\begin{tabular}{|c|c|c|c|c|c|c|c|c|}
\hline \begin{tabular}{|l|} 
sample \\
number
\end{tabular} & $\begin{array}{c}\text { Soil } \\
\text { material }\end{array}$ & depth & KTK & $\mathrm{KB}$ & P total & $\mathrm{K}$ total & C-organic & $\begin{array}{c}\text { Fertility } \\
\text { status }\end{array}$ \\
\hline \begin{tabular}{|l|} 
TS1 \\
\end{tabular} & \multirow{4}{*}{ Peat soil } & \multirow{4}{*}{$<30 \mathrm{~cm}$} & $\mathrm{~T}$ & SR & $\mathrm{S}$ & $\mathrm{S}$ & ST & low \\
\hline TS2 & & & $\mathrm{T}$ & SR & ST & $S$ & ST & medium \\
\hline TS3 & & & $\mathrm{T}$ & SR & ST & $S$ & ST & medium \\
\hline \begin{tabular}{|l|} 
TS4 \\
\end{tabular} & & & $\mathrm{T}$ & SR & ST & $\mathrm{S}$ & ST & medium \\
\hline TS1 & \multirow{4}{*}{ Mineral } & \multirow{4}{*}{$>1 \mathrm{~m}$} & $\mathrm{~T}$ & SR & $\mathrm{R}$ & $\mathrm{T}$ & $\mathrm{S}$ & Low \\
\hline TS2 & & & $\mathrm{T}$ & SR & $\mathrm{R}$ & $\mathrm{R}$ & $\mathrm{S}$ & Low \\
\hline TS3 & & & $\mathrm{T}$ & SR & $\mathrm{R}$ & $\mathrm{R}$ & SR & Low \\
\hline TS4 & & & $\mathrm{T}$ & SR & $\mathrm{R}$ & $\mathrm{R}$ & SR & Low \\
\hline
\end{tabular}

Where: $S R=$ very low, $R=$ low, $S=$ medium, $T=$ high, $S T=$ very high, $S M=$ very acidity

\section{B. Optimizing Vegetable Planting Patterns}

Optimization analysis using Linear Programming consists of primal analysis, dual analysis, sensitivity analysis, and post-optimal analysis. The primal analysis shows a combination of types of vegetables that can provide maximum income. The dual analysis is an assessment of resource use by looking at the value of slack or surplus. Sensitivity analysis is used to see the level of sensitivity to the changes made. While post-optimal analysis is used to see the effect of changing parameters to the optimal solution.

\section{- Primal Analysis}

Data analysis shows that optimal vegetable planting patterns are recommended for farmers to work on. Analysis of optimal planting patterns is carried out by the broad class of farmers. Optimal cropping patterns for farmers can be seen from the reduced cost value of the cropping pattern is zero. The types of vegetables selected in the optimal scheme are vegetables that can provide maximum income with limited available resources. Planting patterns that have a reduced cost value that is not equal to zero are not recommended for farmers to apply. If the cropping pattern is applied, the farm income will be reduced by the value of the reduced cost in each planting pattern.

Optimal cropping patterns of vegetable growers are commodity long beans + cucumbers in planting season 1
(PS1) and planting season 2 (PS2). The results of the analysis of farmer optimization show that the value of the objective function, i.e. farm income under optimal conditions is Rp. $4,289,944$ per year or Rp. $18,619,548$ per hectare per year. The primal analysis shows the number of costs incurred for each activity in the optimal scheme as shown in Table VIII.

Table-VIII. Vegetable farming receipts per hectare farmer in the study area

\begin{tabular}{|c|c|c|}
\hline No & Description & revenue $(\mathrm{Rp} / \mathrm{Ha})$ \\
\hline 1 & Long Beans -PS 1 & $10.810 .730,82$ \\
\hline 2 & Cucumber -PS 1 & $4.897 .922,49$ \\
\hline 3 & Long Beans -PS 2 & $8.349 .000,00$ \\
\hline 4 & Cucumber -PS 2 & $3.719 .230,44$ \\
\hline \multicolumn{2}{|c|}{ Total Revenue } & $27.776 .882,75$ \\
\hline
\end{tabular}

Optimal farm income can be obtained by reducing farm receipts by the total farm costs. Based on the results of the analysis it was found that the total farmer vegetable farming income was Rp. 18,619,548 with an R / C ratio of 3.03.

The reduced cost value of each crop that is not included in the optimal scheme shows that control of one hectare of land on the plant will reduce income by the value of the reduced cost. The reduced cost value for plants that are not included in the optimal planting pattern can be seen in Table IX

Table-IX. Value of reduced cost of plant species per planting season

\begin{tabular}{|l|c|l|r|}
\hline No & Planting Season & \multicolumn{1}{|c|}{ Types of Plants } & Reduced Cost \\
\hline 1 & 1 & Long Beans + Beans & $3.340 .280,00$ \\
\hline 2 & 1 & eggplant & $10.999 .310,00$ \\
\hline 3 & 1 & Corn & $11.440 .350,00$ \\
\hline 4 & 2 & Long Beans + Beans & $2.727 .692,00$ \\
\hline 5 & 2 & eggplant & $3.520 .982,00$ \\
\hline 6 & 2 & Corn & $3.872 .172,00$ \\
\hline 7 & 2 & Long Bean + Tomato & $3.880 .391,00$ \\
\hline 8 & 3 & Corn & $920.583,00$ \\
\hline 9 & 3 & Cucumber & $3.136 .667,00$ \\
\hline 10 & 3 & eggplant & $3.346 .643,00$ \\
\hline
\end{tabular}

Based on Table IX, it can be seen that there are several types of plants that are not recommended for farmers to work on. Types of plants that are not recommended for broad farmers are long beans + beans in PS-1, eggplants in PS-1, corn in PS-1, long beans + beans in PS-2, eggplants in PS-2, corn in PS-2, long beans + tomatoes in PS-2, corn in PS-3, cucumber in PS -3, and eggplant in PS-3. The reduced cost value of the crop shows that the profits of the farmer will be reduced by the value of the reduced cost if the crop is still being cultivated.

\& Sciences Publication 


\section{- Dual Analysis}

The dual value of a scarce or limiting resource is the shadow price of that resource. The addition of one unit of resource will cause a change in the value of the destination in the amount of the shadow price. Resources that are the main obstacle are resources that have the largest shadow price.

The analysis showed that the biggest dual price value for vegetable farmers was land constraints in the first planting season, which amounted to Rp.11,427,200.00. This value indicates the addition of one hectare of land will increase farm income by Rp.11,427,200.00. Optimal analysis results show that land constraints are a limiting resource for vegetable farmers. The available land is used up in two growing seasons, namely PS-1 and PS-2. The value of the dual prices of land constraints for the broad farmer's group for PS-1 and PS-2 is Rp.11,427,200.00 and Rp.7,192,352.00, respectively.

Fertilizer resources are scarce or limited resources for vegetable farmers. The value of dual prices of fertilizer resources in the three growing seasons of vegetable farmers is not equal to zero. This shows that the available fertilizer is used up or is a limited resource.

Labor resources for vegetable farmers are excessive resources. For large farmers, there are excess labor resources in PS I of 64.998726 and 67.42144 in PS II, and 100.00 in PS III. There are excess capital resources for vegetable farmers of Rp16,255,160 in PS-1, Rp.16,941,930 in PS-2 and Rp18,642,760 in -PS-3. Excessive capital resources indicate that there is a waste in allocating agricultural resources.

\section{CONCLUSION}

Soil fertility status in the rejuvenation area of Palm Oil in both materials can be seen that the soil peat material has a relatively better soil fertility status compared to mineral material, which has a range of status from low to moderate. Whereas mineral soil material has a low soil fertility status. This is concluded, although the CEC of this soil sample is classified as high, the cause of the low soil is the P-total, $\mathrm{K}$-total and $\mathrm{C}$-organic content is classified as very low to low.

Optimal cropping patterns of vegetable growers are commodity long beans + cucumbers in planting season 1 and planting season 2 . The results of the farmer optimization analysis show that the value of the objective function, ie farm income under optimal conditions is $\mathrm{Rp} 4,289,944$ per year or $\mathrm{Rp} 18,619,548$ per hectare per year with an $\mathrm{R} / \mathrm{C}$ ratio of 3.03 .

\section{ACKNOWLEDGEMENT}

This research was supported/partially supported by Badan Pengelola Dana Perkebunan Kelapa Sawit (BPDPKS). We thank our colleagues from Lambung Mangkurat University who provided insight and expertise that greatly assisted the research.

\section{REFERENCES}

1. Barkah, B. \& Siddiq, M. (2009). Installation of ditches/canals and community management in the MRPP peat swamp forest area of Musi Banyuasin Regency. Report No. 20 / Final TA / SOP. No. 03. PSF Rehabilitation Rev.0. Palembang, Indonesia: German Technical Cooperation - Merang REDD Pilot Project (MRPP).
2. Biancalani, R., \& Avagyan, A. (2014). Towards Climate-Responsible Peatlands Management. Rome: FAO.

3. Joosten, H., Dommain, R., Haberl, A., Peters, J., Silvius, M., \& Wichtmann, W. (2012). Implementation. In: Joosten, H., Tapio-Bistrom, M.L., \& Tol, S. (eds). Peatlands - guidance for climate change mitigation through conservation

4. Najiyati, S., Muslihat, L., \& Suryadiputra, I.N.N. 2005. Guidance on peatland management for sustainable agriculture. Bogor: Wetlands International. $231 \mathrm{p}$.

5. Noor, M. (2010). Peatlands: Development, Conservation, and Climate Change. Yogyakarta: Gadjah Mada University Press.

6. Mangoensoekardjo S. and Semangun H. (2005). Palm Oil Agribusiness Management. Gadjah Mada Press, Yogyakarta.

7. Mawardi, I. (2007). Rehabilitation and revitalization of ex-peatland development projects in Central Kalimantan. J. Tech. Ling 8 (3): 287-297.

8. Pahan I. (2008). Complete Palm Oil Guide: Agribusiness Management from Upstream to Downstream. Penebar Swadaya, Jakarta.

9. Osaki, M., Nursyamsi, D., Noor, M., Wahyunto, \& Segah, H. (2016) Peatland in Indonesia. In: Osaki, M. \& Tsuji, N. (eds). Tropical Peatlands Ecosystems. Pp: 49-58. Tokyo: Springer.

10. Risza S. (2010). The future of Indonesia's oil palm plantations. Kanisius, Yogyakarta.

11. Ritzema, H., Limin, S., Kusin, K., \& Jauhiainen, J. (2014). Canal blocking strategies for hydrological restoration of degraded tropical peatlands in Central Kalimantan. Catena 114:11-20.

12. Sandrawati, A. (2004). Lesson learned peatland management in Indonesia. Bachelor Thesis. Department of Soil Science. Faculty of Agriculture, IPB. Bogor.

13. Suryadiputra, N. (2007). Options for the rehabilitation of degraded peatland. Technical Meeting and Stakeholder Outreach Workshop on Mining Impacts of Palm Oil and Bio-Fuel Production in SE Asia on Peatlands, Biodiversity, and Climate Change. Kuala Lumpur, 31-October-2 November 2007. [paper presentation].

14. Susanti E., Hutabarat S. and Muwardi D. (2014). Comparative analysis of alternative models of conventional oil palm rejuvenation with an underplanting of the People's Core

15. Whitten, T., Damanik, S.J., Anwar, J., \& Hisyam, N. (2000). The Ecology of Indonesia Series Vol. I: The Ecology of Sumatra. Singapore: Periplus Edition (KH) Ltd.

\section{AUTHORS PROFILE}

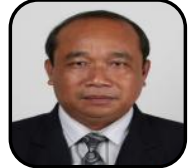

Dr. Taufik Hidayat, is a lecturer at the Faculty of Agriculture, the University of Lambung Mangkurat for undergraduate and Postgraduate Programs. He is also active in research activities at the Center for Population Studies and the Center for Environmental Studies. He concentrated on research relating to aspects of local community wisdom and community empowerment in peat areas and tidal swamps. The Paludiculture research in collaboration with the Republic of Indonesia's Peat Research Agency. he contributed to the publication of the book "Paludiculture Initiation in Indonesia, The Choice of Peatlands Hydrological Unity Commodity Restoration". He has a research fund for oil palm studies on peatlands from the Palm Oil Plantation Fund Management Agency. He is a member of the Indonesian Society of Agricultural Economics.

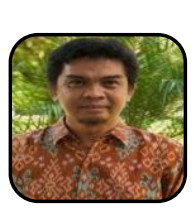

Dr. Fakhrur Razie, Department of Soil Sience, Faculty of Agriculture Lambung Mangkurat University. Banjarbaru, South Kalimantan. Indonesia. Before joining the university, Fakhrur Razie worked as a research assistant of the Japan International Cooperation Agency (JICA). Currently, Fakhrur Razie is a senior lecturer in the Department of Soil Science, Lambung Mangkurat University and he has been involved in several studies: application of Azotobacter to supply nitrogen for plants, system of rice intensification, soil phosphorus dynamics models on dry land treated with bio-porous infiltration system, and modified bio-pore infiltration system to improve micro ecosystems. The last two important studies effort carried out by Fakhrur Razie were the first Paludiculture Research in South Kalimantan and secondly, the Action Research on Intensive Rice Cultivation in the Integrated Farming System in Wetland Lambung Mangkurat University around the World Food Day (WFD) location in Jejangkit Muara - Barito Kuala 
Dr. Yudi Ferrianta, is a lecturer in the Agribusiness Department, University of Lambung Mangkurat, he has 19 years of experience in academics and research. He has a number of research papers in international and national journals. He is a member of the World Economics Association and the editorial board in several International and national journals.

Rifiana, MP, She has 14 years of teaching experience and research, she authored several research papers in International Journals and conferences. She has a member of the Indonesian Society of Agricultural Economics and Agribusiness Association of Indonesia (AAI). She is a recognized researcher. 